\title{
Sunflower seed husk combined with poultry droppings to degrade petroleum hydrocarbons in crude oil-contaminated soil
}

\author{
Sinduja Boopathy, Merline Sheela Appavoo ${ }^{\dagger}$, Ilamathi Radhakrishnan
}

Centre for Environmental Studies,Anna University, Chennai, Tamil Nadu, 600 025, India

\begin{abstract}
To remediate crude oil-contaminated soil, poultry droppings and sunflower seed husk were incorporated at various concentrations. Initially, the $\mathrm{pH}$, moisture content, total organic carbon (TOC), total nitrogen content, and bacterial population of soil, poultry droppings, and sunflower seed husk were determined. The initial bacterial population was $35 \times 10^{8}$ colony forming units/g soil (dry weight basis). The total petroleum hydrocarbon (TPH) content in crude oil-contaminated soil was $7,048.4 \mathrm{mg} / \mathrm{kg}$, in which $857.9 \mathrm{mg} / \mathrm{kg}$ accounted for eicosane. Naphthalene and acenaphthalene were the two polyhydroxy aromatic hydrocarbons present in soil at low concentrations. After the amendment, the $\mathrm{pH}$, moisture content, microbial population, and TPH content of soil were determined on days 20,40 , and 60 . The TPH concentration was considerably decreased in the treatment T4 wherein $250 \mathrm{~g}$ of soil was mixed with $125 \mathrm{~g}$ of poultry droppings and $125 \mathrm{~g}$ of sunflower seed husk. The indigenous bacterial population was also increased tremendously. The dehydrogenase enzyme activity was increased in the amended soil (T4: $0.74 \pm 0.06 \mu \mathrm{g} T \mathrm{TP} / \mathrm{g} / \mathrm{h})$. After the treatment of soil, the germination percentage and vigour index of maize, lady's finger and tomato seeds were enhanced.
\end{abstract}

Keywords: Biodegradation, Petroleum hydrocarbon, Poultry droppings, Sunflower seed husk

\section{Introduction}

Crude oil is a naturally occurring, unrefined petroleum, and yellow-to-black liquid found within the Earth, and it is composed of hydrocarbons, organic compounds, and small amounts of metal [1]. Most of the components present in crude oil have low water solubility because of their low polarity and high substrate hydrophobicity. Soil contaminated with crude oil causes severe environmental issues because crude oil particles bind to soil particles and the contaminated soil particles become nonbioavailable for microorganisms, resulting in poor contact between food and microorganism and thus limiting the rate of mass transfer for biodegradation [2-4]. Furthermore, the contaminated soil possesses complex compounds, such as alkanes, benzenes, and methylbenzenes, and these compounds cannot be easily removed and thus leach into groundwater systems [5]. In addition, these compounds can penetrate through macro- and micropores in soil, thus limiting water and air transport necessary for organic matter conversion [6]. Furthermore, crude oil present in soil may impair aeration and infiltration of water into soil, as well as inhibit plant

This is an Open Access article distributed under the term of the Creative Commons Attribution Non-Commercial License (http://creativecommons.org/licenses/by-nc/3.0/) which permits unrestricted non-commercial use, distribution, and reproduction in any medium, provided the original work is properly cited.

Copyright (C) 2021 Korean Society of Environmental Engineers growth. Thus, the physical properties of soil, including water holding capacity, total porosity, and macro porosity, would be decreased [7]. Various physical and chemical methods employed for treating crude oil-contaminated soil are depicted in Fig. 1.

Considering the demerits of existing technologies, an alternative cheaper and environmentally friendly approach for enhancing petroleum hydrocarbon degradation is required. Studies have used animal and plant waste as a biostimulating agent to remediate crude oil-contaminated soils. For hydrocarbon removal, contaminated soil has been treated with sewage sludge (mixed in a ratio of 7:3) [8]; inorganic fertilisers ( $\mathrm{N}, \mathrm{P}$, and $\mathrm{K}$ ), cow dung, and palm kernel husk ash [9]; aged refuse from landfills [10]; rice husk combined with chicken manure [11]; sawdust [12]; and poultry manure [13]. Agricultural and industrial residues enhanced the colonisation of microorganisms due to favourable sorption properties and high mechanical resistance [14, 15].

The carrier or immobilisation matrix provides a protective microenvironment to microbial inoculants, either physically by providing a protective surface or pore space or nutritionally by providing specific substrates [16]. These materials should be nontoxic both

Received June 26, 2020 Accepted October 14, 2020

${ }^{\dagger}$ Corresponding author

Email: merline@annauniv.edu

Tel: +91 9884216255

ORCID: 0000-0002-4674-588X 


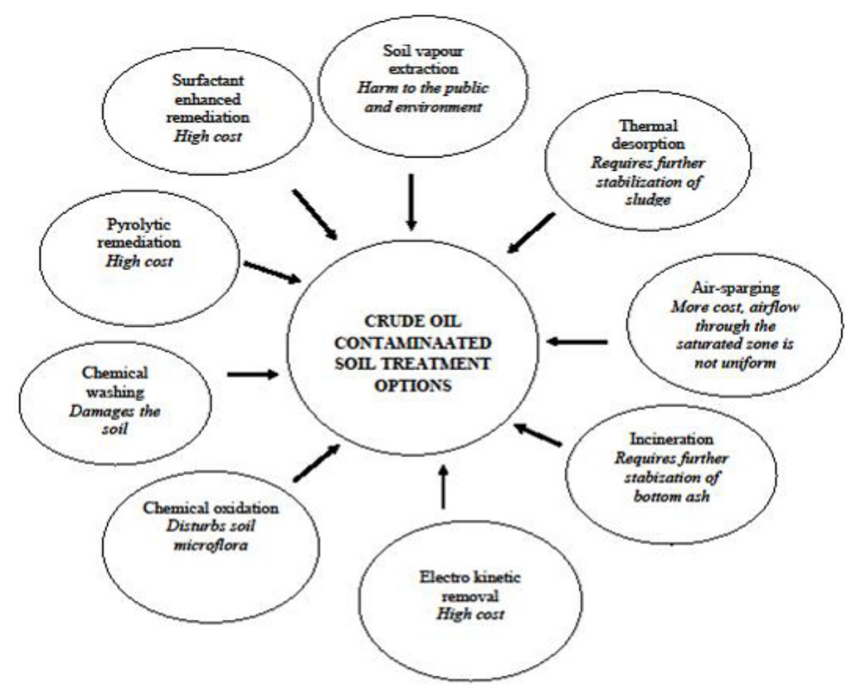

Fig. 1. Illustration showing various physical and chemical methods employed for treating crude oil contaminated soil.

to microbial inoculants and soil organisms and also be biodegradable while possessing such chemical characteristics that enable them to stay in soil long enough for the immobilised bacteria to perform their function.

For the proper maintenance of the biological equilibrium in soil, the physical, chemical, and biological characteristics of soil are crucial $[17,18]$. Any disturbance in soil affects the biological equilibrium because it is susceptible to modifications caused in the ecosystem [18]. However, the stability and fertility of soil are predominantly determined by the activity of enzymes and distribution of microorganisms. Soil harbours numerous enzymes including the representative of all enzyme classes such as oxidoreductases, hydrolases, isomerases, ligases, and transferases. These enzyme groups are involved in the biogeochemical cycling [18] of organic matter for nutrient mineralisation and energy generation [19]. The dehydrogenase enzyme belonging to the oxidoreductase group is considered crucial because it occurs in all living microorganisms [20] and is closely connected with microbiological redox reactions [20]. The dehydrogenase enzyme plays a vital role in indicating pollution in soil, which is known by the absence of the enzyme in the polluted environment. A reduction in enzyme activity and microbial abundance is attributed to the recalcitrant nature and toxicity of compounds [21]. Hence, for remediating such soils, it is essential to increase the microbial profile with necessary enzyme systems capable of degrading pollutants.

North Chennai situated in Tamil Nadu, India, is home to several oil refineries and other heavy industries and thus is one of the most polluted areas in the state capital [22]. A preliminary site analysis showed that alkanes, benzene, toluene, ethylbenzene and xylene (BTEX), and polyaromatic hydrocarbons (PAHs) were found in the soil and groundwater of the Manali region [23]. Because of oil spills in the Manali region, groundwater was heavily contaminated, leading to human health issues [24]. Thus, a cost-effective and environmentally friendly method for removing oil pollution from soil is required. Furthermore, microorganisms present in crude oil-contaminated soil should have a protective shield to degrade pollutants. However, for the efficient degradation of pollutants, the microbial population should be increased by supplementing nutrients to soil. Studies have attempted to remediate crude oil-contaminated soil by using residues of crops and animals for enhancing the nutrient content and increasing the microbial population. However, no study has examined the combined effect of poultry droppings and sunflower seed husk on the remediation of crude oil-contaminated soil. Hence, the present study aimed to remediate crude oil-contaminated soil with sunflower seed husk and poultry droppings.

\section{Materials and Methods}

\subsection{Sample Collection}

\subsubsection{Soil}

The soil sample used in this study was collected from Manali, Tamil Nadu, India $\left(13.1636^{\circ} \mathrm{N}, 80.2586^{\circ} \mathrm{E}\right)$. The area is highly polluted by petroleum products containing a high amount of hydrocarbons, resulting in contaminated soil, surface, and sub-surface water. The soil was collected from outside the industrialised area and near the Santhankadu Lake. The soil sample was collected at a depth of $15 \mathrm{~cm}$ and stored in polythene bags. The soil sample was sieved through a 2-mm mesh to obtain a uniform texture of the soil.

\subsubsection{Poultry droppings}

Poultry droppings (faeces of chickens) were collected from a nearby poultry farming facility. The dropping were dried and ground into powder and stored in plastic containers at $4^{\circ} \mathrm{C}$ without freezing until further use.

\subsubsection{Sunflower seed husk}

The hull of sunflower seeds was bought from Sai Agros Ltd. (Parrys, Chennai, Tamil Nadu, India). The hulls were shredded into smaller pieces, sun dried for a week, ground into powder, and stored in plastic containers at $4^{\circ} \mathrm{C}$ for further study.

\subsection{Characterisation of Soil, Poultry Droppings, and Sunflower Seed Husk}

The $\mathrm{pH}$ was determined using a $\mathrm{pH}$ meter with a soil to water ratio of 1:2.5 and an equilibrium period of $30 \mathrm{~min}[25,26]$. Other parameters, namely moisture content [27], total nitrogen [28], total organic carbon (TOC) by wet oxidation [29], and phosphorus [30], were determined. The bacterial population was estimated using the soil extract agar medium [31]. The oil content of the polluted and remediated soil samples was determined through gas chromatography (GC) by using the toluene extraction method [32] and sonication water bath method [33]. The hydrocarbon content of the samples was determined using GC-mass spectrometry (MS)-Agilent 6890N GC, Santa Clara, USA, equipped with MS and a GC column (DB-5 MS $30 \mathrm{~m} \times 0.25 \mathrm{~mm}$ and $0.25 \mu \mathrm{m}$ ). The heat programme of the column was started at $100^{\circ} \mathrm{C}$ (hold: $2 \mathrm{~min}$ ), which was increased at a rate of $15^{\circ} \mathrm{C} /$ min until it reached $160^{\circ} \mathrm{C}$ and then at a rate of $5^{\circ} \mathrm{C} / \mathrm{min}$ until it reached $280^{\circ} \mathrm{C}$ (hold: 10 $\min )$. Then, $1 \mu \mathrm{L}$ of the extract was injected into the splitless mode 
( $1 \mathrm{~min}$ ). The injector port temperature was set at $200^{\circ} \mathrm{C}$. The detector (Electron Ionization-Mass Spectroscopy) temperature was set at $250^{\circ} \mathrm{C}$ with a nitrogen flow rate at $1.0 \mathrm{~mL} / \mathrm{min}$.

\subsection{Degradation Studies}

The experiment was conducted in plastic containers (upper diameter: $22.6 \mathrm{~cm}$, lower diameter: $13.0 \mathrm{~cm}$, and height: $8.5 \mathrm{~cm}$ ). Each container was filled with $250 \mathrm{~g}$ of crude oil-contaminated soil. The study was conducted with the following treatments, and for each treatment, five replications were maintained [26].

T1: Soil contaminated with crude oil

T2: Soil + Poultry droppings (25 g) + Sunflower seed husk (25 g)

T3: Soil + Poultry droppings (75 g) + Sunflower seed husk (75 g)

T4: Soil + Poultry droppings (125 g) + Sunflower seed husk (125 g)

T5: Soil alone (without crude oil contamination and amendments)

After amendment with poultry manure and sunflower seed husk at various proportions, the experimental setup was kept at room temperature. The $\mathrm{pH}$, moisture content, bacterial population, and total petroleum hydrocarbon (TPH) content of soil were determined at 20,40 , and 60 days. The schematic showing the treatment of crude oil-polluted soil amended with poultry droppings and sunflower seed husk is shown in Fig. S1.

\subsubsection{Microbial activity}

The dehydrogenase enzyme activity, which is the measure of microbial activity, was determined based on the biological reduction of triphenyl tetrazolium chloride (TTC) by microorganisms [34].

Approximately $6.0 \mathrm{~g}$ of soil collected from the different treatments was transferred in $50-\mathrm{mL}$ serum vials, and $0.2 \mathrm{~g}$ of $\mathrm{CaCO}_{3}$ was added to each vial and thoroughly mixed. The content of the vials was fully saturated to a water holding capacity of $100 \%$ by adding $1.0 \mathrm{~mL}$ of $3 \%$ aqueous solution of TTC, $1.0 \mathrm{~mL}$ of $1 \%$ of sucrose solution, and $2.5 \mathrm{~mL}$ of distilled water. The vials were sealed and incubated at $37^{\circ} \mathrm{C}$ for $24 \mathrm{~h}$. Triphenyl Formozan formed in each sample was extracted with hot methanol through filtration. Filtration was performed until the red colour disappeared, and the volume was made to $100 \mathrm{~mL}$ by adding methanol. The intensity of the red colour of the filtrate for each sample was measured using a spectrophotometer at $485 \mathrm{~nm}$ by using methanol as blank. The concentration of formosan for each sample (dehydrogenase activity) was determined by referring to the standard curve of formosan (TPF) in methanol and expressed as $\mu \mathrm{g} / \mathrm{g} / \mathrm{h}$ of the sample.

\subsection{Seed Germination Test}

After treatment with sunflower seed husk and poultry droppings, the suitability of the soil for crop growth was tested. The experiment was conducted using one cereal crop, namely maize (Zea mays L.) var. Co1, and two vegetable crops, namely lady's finger (Abelmoschus esculentus) var. CO1 and tomato (Solanum lycopersicum) var. CO2. Growth parameters, namely the seed germination percentage, vigour index (VI), and mean time to germination, were determined. Initially, the seeds were surface sterilised with $0.58 \%$ sodium hypochlorite for $1 \mathrm{~min}$ and subsequently washed with deionised water and air dried to prevent fungal infection. The seeds were grown in polystyrene Petri plates $(100 \times 15 \mathrm{~mm}$ in size). Each Petri plate was filled with $100 \mathrm{~g}$ of soil obtained after the degradation study (amended with poultry droppings and sunflower seed husk). For comparison, one set of experiment was conducted using soil without any crude oil contamination and amendments. Approximately 20 seeds were placed in each Petri plate, and for each treatment, five replications were maintained. During the experimental period, the moisture content of the soil was maintained at $50 \%$ by spraying sterile water. The germination of seeds was monitored for 20 days, and for every two days, the number of seedlings was counted and removed from the Petri plate. Seed germination was determined based on the final germination percentage, number of days to first germination (delay of germination), and mean time to germination.

The mean time to germination was determined using the following formula [35].

Mean time to germinate $=\Sigma(\mathrm{n} i \times \mathrm{d} i) / \mathrm{N}$, where

$\mathrm{n} i=$ Number of germinated seeds at day $i$

$\mathrm{d}=$ Incubation period in days

$\mathrm{N}=$ Total number of germinated seeds in the treatment

\section{Vigour Index}

VI was calculated on the 7th day [36] using the following formula:

VI $=$ Total length of the seedling $\times$ germination (\%)

The total length of the seedling was measured using a wooden scale, and the values were expressed in $\mathrm{cm} /$ plant.

\subsection{Scanning Electron Microscope analysis}

Bacterial species adsorbed on the amendments were examined using a scanning electron microscope (SEM; Quanta 250 FEG, Thermo Fischer Scientific) [37]. Crude oil-contaminated soil amended with poultry droppings and sunflower seed husk was removed from pots and fixed overnight with $5 \mathrm{mM}$ phosphate buffer $(\mathrm{pH}$ 7.0) with $2.5 \%$ glutaraldehyde for an hour, followed by repeated washing with ethanol at different concentrations $(10 \%, 20 \%, 40 \%$, $60 \%$, $80 \%$, and $100 \%$ ). The samples were dried and prepared using gold sputtering before imaging.

\subsection{Statistical Analysis}

Data were subjected to analysis of variance [38], and differences in significance among the means were compared using Duncan's new multiple range test at a significance level of $5 \%$.

\section{Results and Discussion}

\subsection{Characteristics of Soil, Poultry Droppings, and Sunflower Seed Husk}

The samples of soil, poultry droppings, and sunflower seed husk were analysed for $\mathrm{pH}$, moisture content, TOC, total nitrogen, total phosphorus, and bacterial population, and the results are listed in Table 1.

The $\mathrm{pH}$ of soil, poultry droppings, and sunflower seed husk 
Table 1. Characteristics of Soil and Amendments

\begin{tabular}{lccc}
\hline Parameters & Soil $^{*}$ & Poultry droppings $^{*}$ & Sun Flower Seed Husk $^{*}$ \\
$\mathrm{pH}$ & 8.5 & 7.2 & 5.8 \\
Moisture Content (\%) & 11.4 & 18.0 & 6.5 \\
Total Organic Carbon (\%) & 1.47 & 58.1 & 52.1 \\
Total Nitrogen (\%) & 0.09 & 3.6 & 1.5 \\
Total Phosphorus (\%) & 0.02 & 2.8 & 0.14 \\
Bacterial Population (CFU/g soil dry weight basis) & $35 \times 10^{8}$ & - & - \\
\hline
\end{tabular}

${ }^{*}$ Values represent mean of three determinations CFU - Colony Forming Units

was $8.5,7.2$, and 5.8, respectively. The moisture content of poultry droppings was higher (18\%) than that of soil (11.4\%) and sunflower seed husk (6.5\%). The TOC content of poultry droppings was higher (58.1\%) than that of sunflower seed husk (52.1\%) and soil (1.47\%). The nitrogen content of soil, poultry droppings, and sunflower seed husk was $0.09 \%, 3.6 \%$, and $1.5 \%$, respectively. The phosphorus content of soil, chicken manure, and sunflower seed husk was $0.02 \%, 2.8 \%$, and $0.14 \%$, respectively. The initial bacterial population of soil was approximately $35 \times 10^{8}$ colony forming units (CFUs)/g soil (dry weight basis). Soil characteristics are considered crucial parameters for microbial growth and hydrocarbon degradation. The optimum $\mathrm{pH}$ for microbial growth and organic matter decomposition is 6.5-7.5 [39]. Moreover, soil microbes thrive better in neutral than in acidic soil [39]. An increase in soil $\mathrm{pH}$ towards the neutral condition indicates the presence of more favourable conditions for soil microbes [40]. Soil with a $\mathrm{pH}$ of 5.5-8.8 and a moisture content of $25 \%-80 \%$ enhance microbial growth and biodegradation [41]. However, sunflower seed husk with a moisture content of $<9.0 \%$ [42] can be a stable medium to protect microorganisms in crude oil-contaminated soil [43].

\subsection{Total Petroleum Hydrocarbon Content in Soil}

The TPH content in crude oil-contaminated soil collected from Manali was determined, and the results are shown in Fig. 2. The TPH content of crude oil-contaminated soil was $7,048.4 \mathrm{mg} / \mathrm{kg}$. Among various petroleum hydrocarbons, the concentration of eicosane was the highest $(857.9 \mathrm{mg} / \mathrm{kg})$. The concentration of other

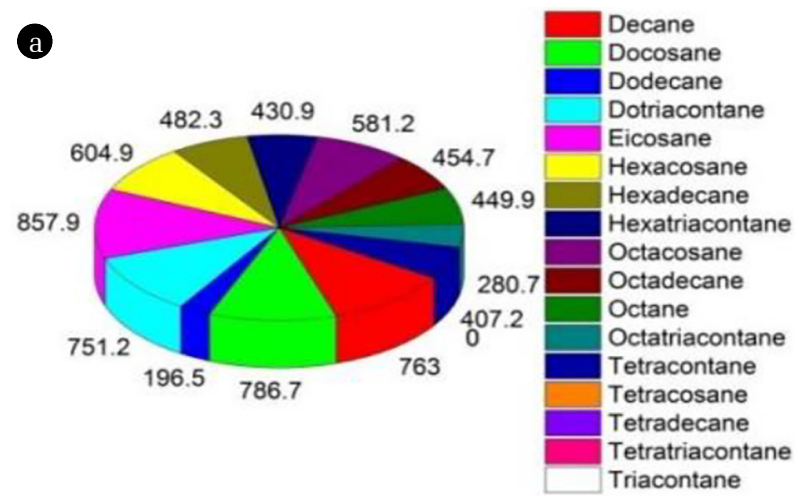

Fig. 2. Hydrocarbons present in the crude oil contaminated soil (mg/kg soil). (a) Total Petroleum hydrocarbons(TPHs), (b) Poly Aromatic Hydrocarbon (PAHs). petroleum hydrocarbon compounds, namely dotriacontane and hexacosane, was 751.2 and $604.9 \mathrm{mg} / \mathrm{kg}$, respectively. The concentration of PAHs, namely naphthalene, phenanthrene, and acenaphthalene, was 0.6, 0.3, and $0.2 \mathrm{mg} / \mathrm{kg}$, respectively. Crude oil contains more than 17000 compounds [44]. Crude oil is a mixture of aliphatic and aromatic hydrocarbons and is complex in nature [45]. However, the composition depends on the source and refining methods [45]. Soil collected from Anatolia had a TPH concentration of 48,000 ppm [46]. In the present study, TPH and PAH concentrations determined in crude oil-contaminated soil was in the range of milligram per kilogram. This result is in agreement with that of a previous study [47]. Furthermore, a study [47] reported that naphthalene, which is one of the 16 Environmental Protection Agency (EPA) $\mathrm{PAHs}$, is present in the highest concentration in crude oil. However, in the present study, soil collected from contaminated sites contained naphthalene $(0.20 \mathrm{mg} / \mathrm{kg})$, phenanthrene (below detection level [BDL]), and acenaphthalene (BDL). Likewise, the naphthalene concentration in soil collected from Manali was higher; this finding is in agreement with those of previous studies [48]. The variation in the TPH concentration in crude oil-contaminated soil collected from different regions might be due to the fact that the extraction efficiency is affected by the ageing and clay content of soil as well as the high molecular weight of PAHs [48].

\subsection{Effect of Amendments on Soil pH, Moisture Content, and Bacterial Population}

The $\mathrm{pH}$ of crude oil-contaminated soil without amendment ranged
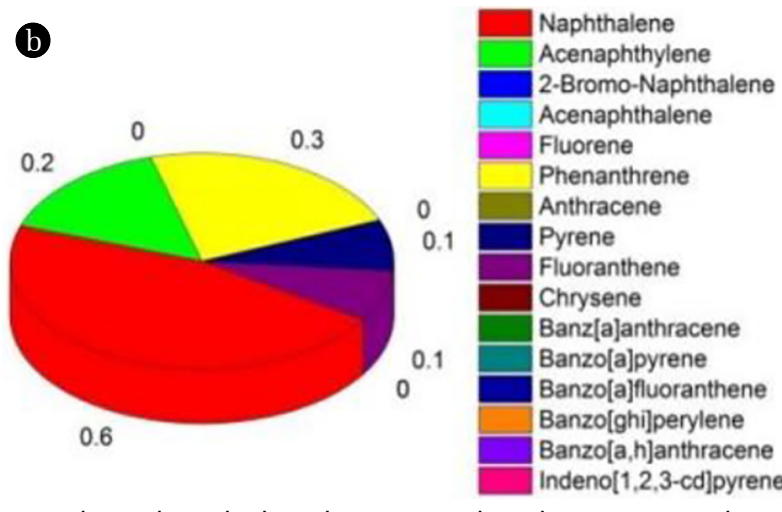

Naphthalene Phenanthrene Anthracene Chrysene Banzo[a]pyrene Banzo[a,h]anthracene indeno[1,2,3-cd]pyrene 

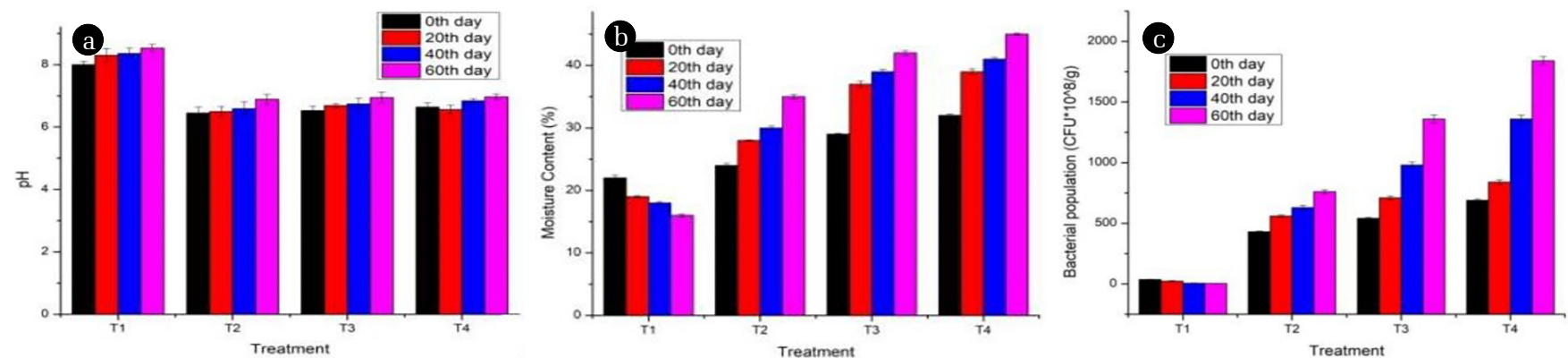

Fig. 3. Effect of amendments on (a) $\mathrm{pH}$, (b) moisture content and (c) bacterial population of crude oil contaminated soil (Error bars showing \pm S.E, $n=5)$.

from $8.0 \pm 0.11$ to $8.5 \pm 0.13(\mathrm{~T} 1)$ for various periods. However, the $\mathrm{pH}$ of soil after the addition of poultry droppings and sunflower seed husk ranged from $6.2 \pm 0.08$ to $6.5 \pm 0.06$ (T2), $6.4 \pm 0.04$ to $6.6 \pm 0.08$ (T3), and $6.3 \pm 0.04$ to $6.6 \pm 0.06$ (T4) for various periods (Fig. 3).

The moisture content of crude oil-contaminated soil after amendment with poultry droppings and sunflower seed husk was determined for regular time intervals, namely on days $0,20,40$, and 60, and the results are illustrated in Fig. 3. The moisture content was higher in soil with amendment than in soil without amendment. Among different time intervals, the highest moisture content was recorded on day 60 , and the moisture content of soil amended with sunflower seed husk and poultry droppings (T4) was higher $(45 \% \pm 0.16 \%)$ than that of soil without amendment $(16 \% \pm 0.25 \%)$.

Soil amended with poultry droppings and sunflower seed husk had a higher bacterial population than did soil without amendment (Fig. 3). The bacterial population was higher on day 60 of treatment (T4; $184 \pm 4.0 \times 10^{9} \mathrm{CFU} / \mathrm{g}$ soil) than for T1 (soil without amendment). The higher bacterial population found in soil amended with sunflower seed husk and poultry droppings might be attributed to nutrients provided by these amendments for the growth of microbial species. Organic amendments have been reported to enhance the multiplication of microorganisms that are capable of degrading and utilising crude oil as the source of carbon and energy [49, 50].

\subsection{Degradation of TPH in Crude Oil-Contaminated Soil}

The TPH content in crude oil-contaminated soil was determined on day 0, 20, 40, and 60, and the results are represented in Fig. 4. In all the treatments (with and without amendments), the degradation of TPH compounds was observed, and the maximum degradation was observed at day 60. The decane concentration was 763 and $674.5 \mathrm{mg} / \mathrm{kg}$ on days 0 and 60 , respectively. The docosane concentration was 786.7 and $350.8 \mathrm{mg} / \mathrm{kg}$ on days 0 and 60 , respectively. Likewise, the concentration of all the TPH compounds was significantly decreased in crude oil-contaminated soil. In all the treatments, a reduction in the concentrations of decane, docosane, dodecane, dotriacontane, eicosane, hexacosane, hexadecane, hexatriacontane, octacosane, octadecane, octane, octatriacontane, and tetracontane was observed on days 20,40 , and 60 . The concentrations of tetracosane, tetradecane, tetratriacontane, and triacontane were BDL from day 20 for the treatments $\mathrm{T} 1, \mathrm{~T} 2, \mathrm{~T} 3$, and $\mathrm{T} 4$.
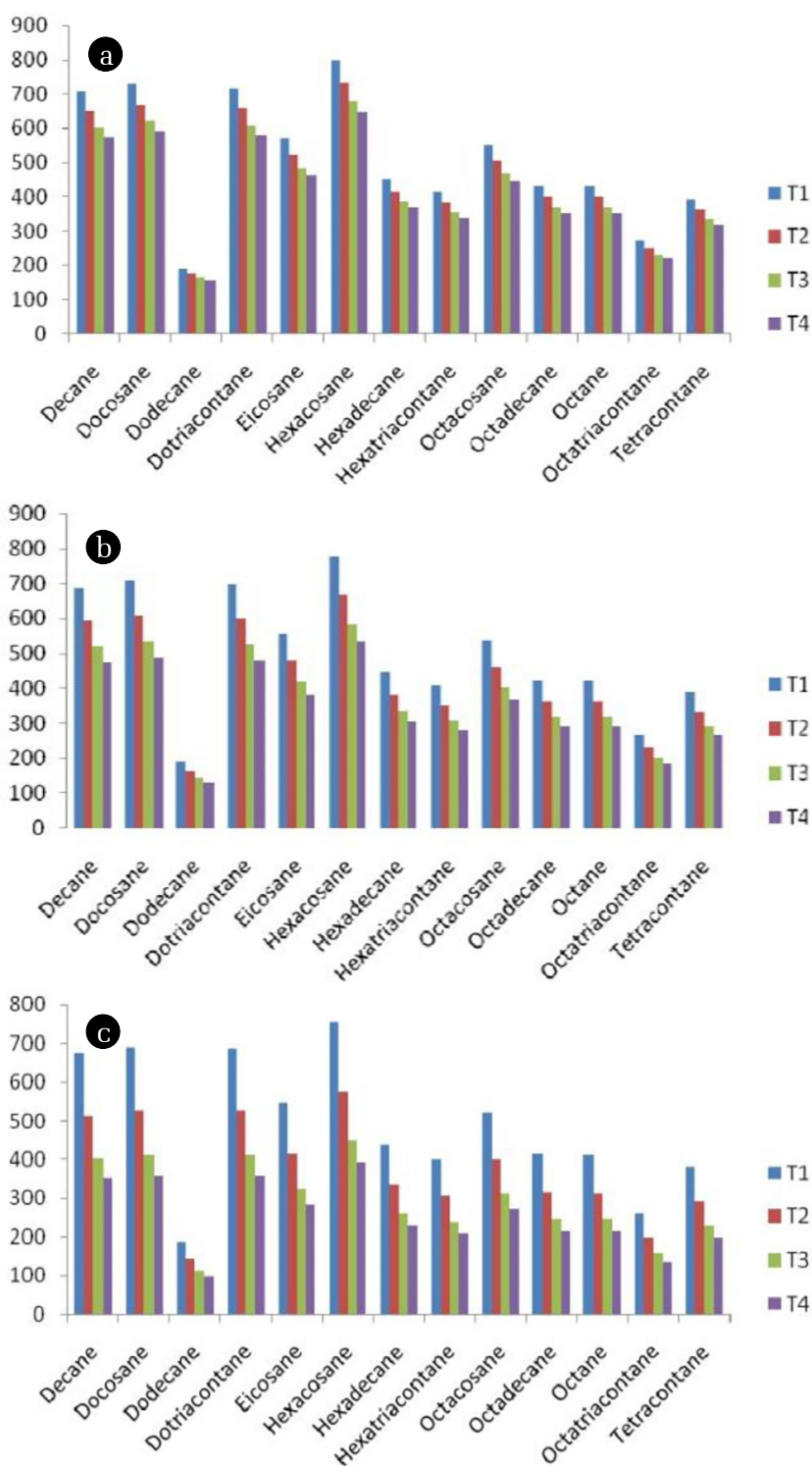

Fig. 4. Total petroleum hydrocarbon (TPH) content in crude oil contaminated soil amended with poultry droppings and sunflower seed husk. (a) 20 days after amendment (b) 40 days after amendment (c) 60 days after amendment. 
Among PAHs present in crude oil-contaminated soil, naphthalene, acenaphthylene, phenanthrene, fluoranthene and pyrene were detected on day 0 , and their concentrations were $0.6,0.2$, 0.3, 0.1 , and $0.1 \mathrm{mg} / \mathrm{kg}$, respectively. Other $\mathrm{PAH}$ molecules, namely 2-bromo-naphthalene, acenaphthalene, fluorene, anthracene, chrysene, banz[a]anthracene, banzo[a]pyrene, banzo[a]fluoranthene, banzo[ghi]perylene, banzo[a,h]anthracene, and indeno [1, 2, 3-cd] pyrene were at BDL. All the PHA molecules were found to be at BDL on days 20, 40, and 60 for all the treatments T1, $\mathrm{T} 2$, T3 and T4.

Sunflower seed husk is used to immobilise microbial culture for degrading crude oil-contaminated soil, and it provides a favourable environment for the survival of microorganisms in soil and improves bioremediation [51]. Poultry droppings, which have a high nitrogen content, can serve as soil amendments by adding organic matter as well as by improving the physical properties of soil and soil fertility by adding essential nutrients that improve moisture and nutrient retention. Furthermore, poultry dropping provide essential nutrients for the habitation of microbes, which can produce beneficial metabolites that indirectly reduce the amount of pollutants in soil [52]. Thus, essential nutrients from poultry droppings are crucial for necessary colonisation and survival in order to achieve better activity of microorganisms to mitigate recalcitrant hydrocarbon contaminants from soil. However, the potential of the bacterial community to remediate crude oil determines the treatment efficiency. An increase in the number of water-holding pores and a decrease in the number of water-transmitting pores [53] may be responsible for the increased moisture content in amended soil. Microorganisms present in soil require water for their metabolic activities. Soil water helps in chemical and biological activities of soil [54]. The organic matter present in soil improves binding and water retention [55] as well as promotes aggregate formation [56]. The presence of low organic matter in soil can be a cause of low water accumulation in soil without amendment [57].

Soil amended with 50\% amendment material exhibited a higher hydrocarbon-degrading bacterial count compared with control. The high concentration of the amended material supported the growth of crude oil degrading-bacteria in soil; thus, significant stimulation of such bacterial populations was observed [58]. The extent of degradation of hydrocarbons was concurrently improved, indicating that microbial degraders were dependent on amendment supply that acts as a nutrient material. Among different amendment concentrations tested, $50 \%$ of the amendment material improved degradation of both aliphatic and aromatic hydrocarbons.

In the present study, higher degradation was observed in soil amended with sunflower seed husk and poultry droppings, and the highest degradation efficiency was shown by the treatment T4 (soil amended with $125 \mathrm{~g}$ of poultry droppings and $125 \mathrm{~g}$ of sunflower seed husk). Nutrient addition can stimulate the growth of petroleum-degrading microorganisms [59]. Indigenous microbial species were biostimulated by the amendments, and poultry litter is very high in nutrients, such as nitrogen, phosphorus, and potassium, and is used as a high-quality soil conditioner [60, 61]. Sunflower seed husk is composed of lipids, cellulose, and the reduced sugar pentose, and it provides a microenvironment for microorganisms present in soil to multiply and degrade pollutants [62]. In this study, PAH molecules were degraded in all the treatments, and PAH-degrading organisms, such as Sordariomycetes, Actinobacteria, Betaproeobacteria, and Gammaproteobacteria, are capable of degrading TPH molecules in soil [63]. The PAH benzopyrene could be degraded within 18 days by a novel strain that utilises this compound as the sole carbon source [64].

\subsubsection{Dehydrogenase enzyme activity of crude oil-contaminated soil after treatment}

The dehydrogenase enzyme activity of crude oil-contaminated soil treated with poultry droppings and sunflower seed husk was determined after 60 days, and the results are shown in Table 2. For comparison, garden soil (with no prior history of crude oil contamination) was also tested for the dehydrogenase enzyme activity.

Crude oil-contaminated soil amended with $125 \mathrm{~g}$ of poultry droppings and $125 \mathrm{~g}$ of sunflower seed husk exhibited the highest dehydrogenase enzyme activity of $0.74 \pm 0.06 \mu \mathrm{g} \mathrm{TPF} / \mathrm{g} / \mathrm{h}$, followed by control soil (without crude oil contamination and amendments) at $0.66 \pm 0.08 \mu \mathrm{g} \mathrm{TPF} / \mathrm{g} / \mathrm{h}$. However, the other two treatments (soil with crude oil contamination and amended with $25 \mathrm{~g}$ of poultry droppings and $25 \mathrm{~g}$ of sunflower seed husk and $75 \mathrm{~g}$ of poultry droppings and $75 \mathrm{~g}$ of sunflower seed husk, respectively) showed a dehydrogenase enzyme activity of $0.62 \pm 0.06$ and $0.65 \pm 0.08$ $\mu \mathrm{g} \mathrm{TPF} / \mathrm{g} / \mathrm{h}$, respectively. The lowest dehydrogenase enzyme activity of $0.08 \pm 0.04 \mu \mathrm{g} \mathrm{TPF} / \mathrm{g} / \mathrm{h}$ was shown by soil with crude oil contamination and not amended with the substrates.

Compared with soil without amendment, increased dehydrogenase enzyme activity was observed in crude oil-contaminated soil amended with poultry droppings and sunflower seed husk. The addition of crop residues enhanced the soil enzyme activity [65]. Furthermore, organic amendments have been reported to increase the microbial population in soil and induce soil properties to regulate the soil microbial community [66, 67]. The added amendments supplied nutrients for the growth of indigenous oil-degrading micro-

Table 2. Dehydrogenase Enzyme Activity of Crude Oil Contaminated Soil 60 days after Treatment

\begin{tabular}{lc}
\hline Treatments & TPH $\mathbf{p r o d u c e d ~}\left(\boldsymbol{\mu g} \mathbf{~ T P F ~} \mathbf{g}^{-1} \mathbf{h}^{-1}\right)$ \\
\hline Control (uncontaminated soil) & $0.66 \pm(0.08)$ \\
Contaminated soil & $0.08 \pm(0.04)$ \\
Soil + Poultry droppings (25 g) + Sunflower Seed husk (25 g) & $0.62 \pm(0.06)$ \\
Soil + Poultry droppings (75g) + Sunflower Seed husk (75g) & $0.65 \pm(0.08)$ \\
Soil + Poultry droppings (125g) + Sunflower Seed husk (125g) & $0.74 \pm(0.06)$ \\
\hline
\end{tabular}

Values in parenthesis show Standard Error $(n=5)$ 
organisms in soil, which in turn increased the dehydrogenase enzyme activity [15, 68]. In the present study, the highest dehydrogenase enzyme activity was observed in the treatment incorporating sunflower seed husk and poultry droppings. Many studies have reported that organic amendments can increase enzyme synthesis $[69,70]$ and production by soil microorganisms as well as promote the release of enzymes that are either immobilised by clay and humic particles or entrapped within soil aggregates [71].

\subsubsection{SEM analysis}

On day 60 after the treatments, bacterial species adhered on the amendments, namely poultry droppings and sunflower seed husk, used for remediating crude oil-contaminated soil were analysed using SEM, and the results are shown in Fig 5. Adherence of bacterial cells was noticed on both the amendments. The adherence of bacterial species on organic amendments improved the tolerance of bacterial cells to toxic pollutants [72]. Many studies have been conducted using different amendments, such as biochar [73], goethite [74], and coconut coirpith [15], to immobilise bacterial species to remediate contaminated sites. However, the adhesion of bacterial species on organic matter could be achieved by polysaccharides produced by bacterial species [75].

\subsection{Plant Toxicity Test}

The effect of crude oil contamination on the germination of maize, tomato, and lady's finger seeds was determined. Parameters, namely the percentage of germination, mean time to germinate, delay in germination, and VI, were determined.

In the present study, the percentage of germination for maize varied from $50 \%$ to $100 \%$ for various treatments. The lowest germination of $50 \%$ was recorded for the treatment $\mathrm{T} 1$ (crude oil-contaminated soil without amendments), whereas $100 \%$ germination was observed in control soil without crude oil contamination (T5). For the treatment T4 (crude oil-contaminated soil amended with $125 \mathrm{~g}$ of poultry droppings and $125 \mathrm{~g}$ of sunflower seed husk), 95\%of germination was observed (Table 3).

The mean time to germination was 4 and 9 days, for seeds sown in uncontaminated soil (control) (T5) and crude oil-contaminated soil (T1), respectively. The mean time to germination for soil amended with $125 \mathrm{~g}$ of poultry droppings and $125 \mathrm{~g}$ of sunflower seed husk (T5) was 4 days, which was the same as that for uncontaminated soil (T5) (Table 3). Germination started on day 4 of sowing in all the treatments, except in crude oil-contaminated soil without amendments (T1). In crude oil-contaminated
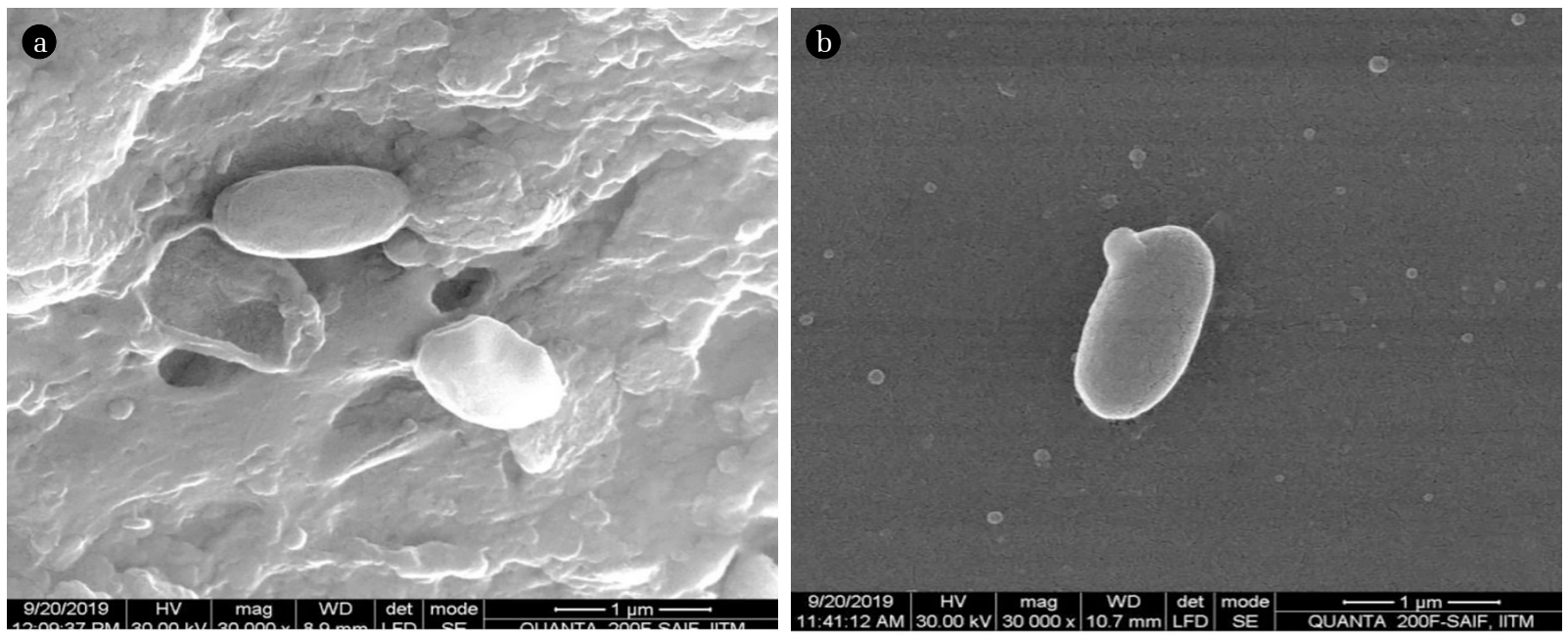

Fig. 5. Scanning Electron Micrograph (SEM) of (a) bacterial cells in soil amended with poultry droppings (b) bacterial cells in soil amended with sunflower seed husk.

Table 3. Germination of Maize (Zea mays L.) var. CO 1 Seeds in Crude Oil Contaminated Soil (60 days after Treatment)

\begin{tabular}{|c|c|c|c|c|c|}
\hline S. No & Treatment.s & $\begin{array}{c}\text { Germination }^{*} \\
(\%)\end{array}$ & $\begin{array}{l}\text { Mean Time to Germinate } \\
\text { (days) }\end{array}$ & $\begin{array}{l}\text { Delay in germination* } \\
\text { (days) }\end{array}$ & Vigour Index \\
\hline $\mathrm{T} 1$ & Contaminated soil & 50 & 9.0 & 8 & 175.0 \\
\hline $\mathrm{T} 2$ & $\begin{array}{l}\text { Soil + Poultry droppings (25 g) + } \\
\text { Sunflower Seed husk (25 g) }\end{array}$ & 80 & 4.4 & 4 & 544.0 \\
\hline T3 & $\begin{array}{l}\text { Soil + Poultry droppings (75g) + } \\
\text { Sunflower Seed husk (75g) }\end{array}$ & 88 & 4.2 & 4 & 633.6 \\
\hline $\mathrm{T} 4$ & $\begin{array}{l}\text { Soil + Poultry droppings (125g) + } \\
\text { Sunflower Seed husk (125g) }\end{array}$ & 95 & 4.0 & 4 & 769.5 \\
\hline T5 & Control (uncontaminated soil & 100 & 4.0 & 4 & 800.5 \\
\hline
\end{tabular}

${ }^{*}$ Values represent mean of five determinations 
soil, germination was delayed, and it started only on day 8 . The VI of the seeds was calculated on day 7. The seeds grown in crude-oil contaminated soil (T1) showed the lowest VI value of 175 . The highest VI value of 800.5 was observed for the seeds sown in uncontaminated soil (T5), followed by 769.5 for the seeds grown in crude oil-contaminated soil amended with $125 \mathrm{~g}$ of poultry droppings and $125 \mathrm{~g}$ of sunflower seed husk (T4) (Table 3).

The germination varied from $10 \%$ to $100 \%$ for the various treatments (Table S1) for lady's finger. The treatment in which crude oil-contaminated soil was amended with $125 \mathrm{~g}$ of poultry droppings and $125 \mathrm{~g}$ of sunflower seed husk (T5) showed the highest germination of $100 \%$, which is the same as that observed for uncontaminated soil (T5). In crude oil-contaminated soil (without any addition of amendments; T1), germination was the lowest (10\%). The mean time to germinate the seeds of lady's finger in crude oil-contaminated soil (T1) was 14 days. However, for the uncontaminated soil (T5) and crude oil-contaminated soil amended with $125 \mathrm{~g}$ of poultry droppings and $125 \mathrm{~g}$ of sunflower seed husk (T4), the mean time to germination was 4 and 5 days, respectively.

Germination started at 4 and 5 days, respectively, for uncontaminated soil (T5) and crude oil-contaminated soil with $125 \mathrm{~g}$ of poultry droppings and $125 \mathrm{~g}$ of sunflower seed husk (T4). In contaminated soil without any amendments (T1), germination was delayed by 14 days. The highest VI value of 1000 was expressed by the lady's finger seeds sown in uncontaminated soil (T5) and crude oil-contaminated soil amended with $125 \mathrm{~g}$ of poultry droppings and $125 \mathrm{~g}$ of sunflower seed husk (T4). The seeds grown in contaminated soil without any amendments (T1) showed the lowest VI value of 70 .

For tomato, germination varied from $10 \%$ to $100 \%$ for the various treatments. The treatment in which crude oil-contaminated soil was amended with $125 \mathrm{~g}$ of poultry droppings and $125 \mathrm{~g}$ of sunflower seed husk (T4) and uncontaminated soil (T5) showed the highest germination of $100 \%$. The lowest germination of $10 \%$ was observed in crude oil-contaminated soil (without any addition of amendments; T1) (Table S2). The mean time to germinate the seeds of tomato in uncontaminated soil (T5) and crude oil- contaminated soil amended with $125 \mathrm{~g}$ of poultry droppings and $125 \mathrm{~g}$ of sunflower seed husk (T4) was 4 days. However, the mean time to germinate the seeds in contaminated soil without amendments was 15 days.

Germination was delayed by 14 days in contaminated soil (T1) without amendments. The mean to germination for Uncontaminated soil (T5) and crude oil-contaminated soil with $125 \mathrm{~g}$ of poultry droppings and $125 \mathrm{~g}$ of sunflower seed husk (T4) was 4 and 3 days, respectively.

The highest VI value of 1100 was exhibited by the tomato seeds sown in crude oil-contaminated soil amended with $125 \mathrm{~g}$ of poultry droppings and $125 \mathrm{~g}$ of sunflower seed husk (T4), followed by the seeds sown in uncontaminated soil (T5) (1000). The seeds grown in contaminated soil without any amendments (T1) showed the lowest VI value of 60 .

The germination of the seeds in crude oil-contaminated soil was only $50 \%$ when compared with other treatments. Furthermore, the mean time to germination and delay in germination were found to be higher in contaminated soil. The results of the present study are in accordance with those of previous studies [76, 77]. Furthermore, the germination of Archis hypogea and Sorghum bi- color was $100 \%$ in soil without crude oil contamination but lower in crude oil-contaminated soil [78]. Oil contamination in soil inhibits plant growth and biomass production [79]. In the present study, the seeds sown in soil after treatment with amendments, namely poultry droppings and sunflower seed husk, exhibited better performance, and this might be due to the reduction in toxicity resulting from the efficient enhancement of degradation of hydrocarbons present in soil by the organic amendments [80]. When wastewater sludge was composted and used as an amendment in hydrocarbon-contaminated soil, there was a reduction in phytotoxicicity and an increase in the germination percentage [81]. Poor germination, low VI, and delay in germination are attributed to the inherent toxicity caused by hydrocarbon compounds in soil and plants due to hydrophobic properties [77]. In addition, the film or coating formed over the seed or root surface acts as a physical barrier, hindering gaseous exchange, water uptake, and nutrient absorption [82]. Furthermore, the cell membranes of plants are damaged by hydrocarbons, which in turn affect the metabolic transport and respiration rate [83]. In the current study, the experiment was conducted only for 60 days. If the experiment would have been performed for additional days, complete degradation of hydrocarbons might have occurred, and soil would have been suitable for growing crops. A field-level study is needed for remediating contaminated soils with locally available agricultural residues.

\section{Conclusions}

The results of the present study indicated that crude oil-contaminated soil could be remediated using sunflower seed husk and poultry droppings. A considerable reduction in TPH compounds was observed when $250 \mathrm{~g}$ of soil was mixed with 125 $\mathrm{g}$ of poultry droppings and $125 \mathrm{~g}$ of sunflower seed husk. The highest bacterial population of $184 \pm 4.0 \times 10^{9} \mathrm{CFU} / \mathrm{g}$ soil was observed in the treatment T4. The dehydrogenase enzyme activity was found to be $0.74 \pm 0.06 \mu \mathrm{g} \mathrm{TPF} / \mathrm{g}$ soil/h. This could be possible because microorganisms have various enzyme pathways to degrade and utilise different hydrocarbons as the source of carbon and energy. Furthermore, after the treatment with the amendments, the phytotoxicity of soil was reduced. The treated soils enhanced the germination of the seeds within a short period. The germination of the crops tested was $100 \%$, and the highest VI value was obtained. From this study, it can be concluded that hydrocarbon contamination of soil, which is a global issue, can be solved by the addition of organic amendments, namely poultry droppings and sunflower seed husk, which are easily available and inexpensive. Furthermore, remediated soil can be a suitable medium for growing plant species.

\section{Author Contributions}

S.B. (M.E. student) conducted the experiment and wrote the original draft. M.S.A. (Assistant Professor) supervised the student and edited the manuscript, and I.R. (Ph.D student) conducted scanning electron microscope studies. 


\section{References}

1. Cooney JJ, Silver SA, Beck EA. Factors influencing hydrocarbon degradation in three freshwater lakes. Microb. Ecol. 1985;11: 27-137.

2. Paria S. Surfactant Enhance Remediation of Organic Contaminated Soil and Water. Adv. Colloid. Interface. Sci. 2008;138(1):24-58.

3. Lai CC, Huang YC, Wei YH, Chang JS. Biosurfactant- enhanced removal of total petroleum hydrocarbons from contaminated soil. J. Hazard. Mater. 2009;167:609-614.

4. Kuyukina MS, Ivshina IB, Makarov SO, Litvinenko LV, Cunninggham CJ, Philip J. Effect of biodurfactant on crude oil desorption and mobilization in a soil system. Environ. Int. 2015;3(2):155-161.

5. Ren L, Shi Y, Jia Y, Yan Y. Genome sequence of Arthrobacter $s p$. YC-RL1, an aromatic compound-degrading bacterium. Genome Announc. 2015;3(4):e00749-15.

6. Caravaca F, Roldan A, Assessing changes in physical and biological properties in a soil contaminated by oil sludges under semiarid Mediterranean condition. Geoderma. 2003;117:53-61.

7. Ewetola EA, Effect of crude oil pollution on some soil physical properties, IOSR J. Agric. Vet. Sci. 2013;6:14-17.

8. Al-Kindi S, Abed RMM. Effect of biostimulation using sewage sludge, soybean meal and wheat straw on oil degradation and bacterial community composition in a contaminated desert soil. Front. Microbiol. 2016;7:240.

9. Otoko GR, Honest BK. Stabilization of Nigerian Deltaic Laterites with Sawdust Ash. Int. J. Scientific Res. Manage. 2014;2(8): 1287-1297.

10. Liu Q, Li Q, Wang N, et al. Bioremediation of Petroleum-contaminated soil using aged refuse from landfills. Waste Manage. 2018;77:576-585.

11. Adams FV, Niyomugaba, Sylvester OP. Bioremediation of crude oil contaminated soil using Agricultural wastes. Procedia Manufact. 2017;7:459-464.

12. Alvim GM, Pontes PP. Aeration and Sawdust application effects as structural material in the bioremediation of clayey acid soils contaminated with diesel oil. Int. Soil Water Conser. Res. 2018;6(3):253-260.

13. Onwuka KE, Igwe KVC, Christopher E. Bioremediation of Crude oil polluted soil using Poultry droppings. Int. J. Zambrat. 2019;2(1):65-73.

14. Merline Sheela A, Shanmugasundaram R, Sundaram MD. Effect of organic amendments on the oxygen uptake of Pseudomonas putida- PAPs -1 in chromium contaminated pond ash. Soil Sediment Contam. 2005;14(1):71-84.

15. Annie G, Merline SA, Ilamathi R. Fate of crude oil in soil treated with Pseudomonas putida immobilised on coconut coirpith a low cost biocarrier. Soil Sediment Contam. 2020;1-18.

16. Mishra S, Jyot J, Kuhad RC, Lal B. Evaluation of inoculum addition to stimulate insitu bioremediation of oily-sludge-contaminated soil. Appl. Environ. Microbiol. 2001;67:1675-1681.

17. Kumar A, Sharma MP, Taxak AR. Effect of vegetation communities and altitudes on the soil organic carbon stock in Kotli - IA Catchment, India. Clean (Weinh) 2017;45(8):1600650.

18. Kumar A, Mishra S, Kumar M, Singhal S. Environmental quantification of soil elements in the catchment of hydroelectric reser- voirs in India. Hum. Ecol. Risk Assess. 2017;23(5):1202-1218.

19. Moeskops B, Sukristiyonubowo, Buchan D, et al. Soil microbial communities and activities intensive organic and conventional vegetable farming in West Java, Indonesia, Appl. Soil Ecol. 2010;45(2):112-120.

20. Kaczynska G, Borowik A, Wyszkowska J. Soil dehydrogenases as an indicator of contamination of the environment with petroleum products. Water Air Soil Pollut. 2015;226:372.

21. Perez-Leblic MI, Turmero A, Hernandez M, et al. Influence of xenobiotic contaminants on landfill soil microbial activity and diversity. J. Environ. Manage. 2012;95:5285-5290.

22. Antony SA, Balakrishnan M, Gunasekaran SA. Correlation study of the ground water quality in the Manali Petroleum Indutrial regions in Tamil Nadu, India. Ind. J. Sci. Technol. 2008;1(6):1-11.

23. Nambi IM, Rajasekhar B, Loganathan V, Ravikrishna R. An assessment of subsurface contamination of an urban coastal aquifer due to oilspill. Environ. Monit. Assess. 2017;189(4):1-17.

24. Rajasekhar B, Nambi I, Sureshkumar G. Characterization of petroleum contaminated groundwater due to an inland oil spill in Chennai and human health risk assessment by probabilistic methods, Oil Spill India 2018, $5^{\text {th }}$ and $6^{\text {th }}$ July 2018, Environment and Water Resources Engineering, Department of Civil Engineering, IIT Madras.

25. Kumar A, Sharma MP, Yang T. Estimation of carbon stock for greenhouse gas emissions from hydropower reservoirs. Stoch. Environ. Res. Risk Assess. 2018;32:3183-3193.

26. Kumar A, Sharma MP. Estimation of greenhouse gas emissions from Koteshwar hydropower reservoir, India. Environ. Monit. Assess. 2017;89:240.

27. Black CA. Methods of Soil Analysis: Part I Physical and mineralogical properties, including statistics of measurement and sampling. Am. Soc. Agron. Madison, Wisconsin;1965.

28. Nelson DW, Sommers LE. Total carbon, organic carbon and organic matter. In: Page AL, Miller RH, Keeney DR eds. Methods of soil analysis, part 2. Am. Soc. of Agron. Madison; 1982. p. 539-579.

29. Allison LE. Wet-combustion apparatus and procedure for organic and inorganic carbon in soil. Soil. Sci. Sot. Am. Proc. 1960;24:36-40.

30. Olsen SR, Cole CV, Watanabe PS, Dean L. Estimation of available phosphorus in soils by extraction with sodium carbonate. U. S. Dept. of Agric. Cir.1954; p. 939.

31. Allen ON. Experiments in Soil Bacteriology.3rd Revised ed. Burgess Publ. Co. 1957.

32. Okafor UC, Orji MU, Nwankwegu AS, et al. Effect of Chicken droppings amendments on bioremediation of crude-oil polluted soil. Eur. J. Exp. Biol. 2016;6(4):62-68.

33. Odu CTI. Degradation and Weathering of crude oil under Tropical Condition Proceeding of the International Seminar on the Petroleum Industry and the Nigerian Environment, November 1981, Warri, Nigeria.143-153.

34. Casida LE Jr, Klen DA, Santaro T. Soil dehydrogenase activity. Soil Sci. 1964;98:371-376.

35. Maraghni M, Gorai M, Neffati M. Seed germination at different temperature and water stress levels and seedling emergence from different depths of Zizyphus lotus. S. Afr. J. Bot. 2010;76(3):453-459. 
36. Abdul A, Anderson JD. Vigour determination in Soybean seed by multiple criteria. Crop. Sci. 1973;13:630-633.

37. Caldeira M, Heald SC, Carvalho MF, Vasconcelos I, Bull AT, Castro PML. 4 - Chloramphenicol degradation by a bacterial consortium: development of a granular activated carbon biofilm reactor. Appl. Microbiol. Biotechnol. 1999;52:722-729.

38. Snedecor GW, Cochran WG. Statistical methods applied to experiments in agriculture and biology. 5th ed. Ames, Iowa: Iowa State University Press.1956.

39. Song M, Luo C, Li F, et al. Anaerobic degradation of Polychlorinated Biphenyls(PCBs) and Polychlorinated Biphenyls Ethers(PBDES) and microbial community dynamics of electronics waste-contaminated soil. Sci. Tot. Environ. 2015;502(1):426-433.

40/ Atlas RM, Bartha R. Stimulated Petroleum Biodegradation, Crit. Rev. Microbiol. 1977;5:371-386.

41. Maletić S, Dalmacija B, Rončević S, Agbaba J, Petrović O. Degradation Kinetics of an Aged Hydrocarbon-Contaminated Soil. Water Air Soil Pollut. 2009;202:149-159.

42. Maj G, Krzaczek P, Kuranc A, Piekarski W. Energy properties of sunflower seed husk as industrial extrusion residue. Agri. Engineer. 2017;21(1):77-84.

43. Cubitto MA, Gentili AR. Bioremediation of crude oil-contaminated soil by immobilized bacteria on an agroindustrial waste-Sunflower seed husks. Bioremediat. J. 2015;19:277-286.

44. Marshall AG, Rodgers RP. Petroleomics: The next grand challenge for chemical analysis. Acc. Chem. Res. 2004;37(1):53-59.

45. Gallego JL, Loredo J, Llamass JF, Vasquez F, Sanchez J. Bioremediation of diesel - contaminated soils: evaluation of potential in situ techniques by study of bacterial degradation. Biodegrad. 2001;12(5):325-335.

46. Ustun Kurnaz S, Buyukgungor H. Bioremediation of total petroleum hydrocarbons in crude oil contaminated soils obtained from Southeast Anatolia. Acta Biologica Turica. 2016;29(2): 57-60.

47. Bada BS, Egbeja TI, Arowolo TA, Obuotor TM. Degradation of total petroleum hydrocarbon in petroleum products - contaminated soil using pig dung. West Afr. J. Appl. Ecol. 2019;27(2):1-15.

48. Schwab AP, Su J, Wetzel S, Pekarek S, Banks MK. Extraction of petroleum hydrocarbons from soil by mechanical shaking. Environ. Sci. Technol. 1999;33:1940-1945.

49. Stround JL, Paton G I, Semple K T. Microbe - aliphatic hydrocarbon interactions in soil implications for biodegradation and bioremediation. J. Appl. Microbiol. 2007;102(5):1239-1253.

50. Ogoko EC. Evaluation of polycyclic aromatic hydrocarbons, total petroleum hydrocarbons and some heavy metals in soils of Nnpc Oil Depot Aba Metropolis, Abia State, Nigeria. OSR J Environ. Sci. Toxicol. Food Technol.2014;8(5):21-27.

51. Itodo AU, Akeju TT, Itodo HU. Polycyclic aromatic hydrocarbons in crude oil contaminated water from Ese-Odo offshore, Nigeria. Annals Ecol. Environ. Sci. 2019;3(1):12-19.

52. Marshal TR. Biodegradation of Petroleum wastes in soil, The Microbial Ecosystem and the Optimization of a Treatment Process, Doctoral Thesis, University of Southern California, California, USA, 1988.

53. Yemashova NA, Murygina VP, Zhukov DV, et al.
Biodeterioration of crude oil and oil derived products: a review. Rev. Environ. Sci. Bio. 2007;6(4):315-337.

54. Razak ZA, Baker RA, Ahmed SH, Othman R. Effect of rice husk biochar and chicken manure as a soil amendment on yield, heavy metals and nutrient uptake of Phyllanthus niruri. Int. J. Agric. Environ. Res. 2017;3(5):3667.

55. Ali N, Eliyas M, Al-Sarawi H, Radwan SS. Hydrocarbon-utilising microorganisms naturally associated with sawdust. Chemosphere 2011;83(9):1268-1272.

56. Dibble JT, Bartha R. The effect of iron on the biodegradation of petroleum in seawater. Appl. Environ. Microbiol. 1976;31: 544-550.

57. Vieira GAL, Magrina MJ, Bonugli-Santos RC, Rodrigues MVN, Sette $\mathrm{LD}$. Polycyclic aromatic hydrocarbon degradation by marine-derived basidiomycetes: Optimization of the degradation process. Brazil J. Microbiol. 2018;49(4):749-756.

58. Akanni DI, Ojeniyl SO. Residual effect of goat and poultry manures on soil properties, Nutrient content and yield of Amaranthus in Southwest Nigeria. Res. J. Agron. 2008;2:44-47.

59. Adler PR, Arora R, El Ghaouth, Glenn DM, Sola JM. Bioremediation of Phenolic Compounds from water with plant root surface peroxidases. J. Environ. Qual. 1994;23:1113-1117.

60. Chaineau CH, Rougeux G, Yepremian C, Oudot J. Effects of nutrient concentration on the biodegradation of crude oil and associated microbial populations in the soil. Soil Biol. Biochem. 2005;37(8):1490-1497.

61. Wu M, Dick WA, Li W, et al. Bioaugmentation and biostimulation of hydrocarbon degradation and the microbial community in Petroleum-contaminated soil. Int. Biodeter. Biodegrad. 2016; 107:158-164.

62. Dulolio FS, da Silva JN, Carneiro, et al. Poultry litter as biomass - energy: a review and future perceptive. Renew. Sustain. Energy Rev. 2017;76:941-949.

64. Adeyemo AJ, Akinbola OO, Ojeniyl SO. Effects of poultry manure on soil infiltration, organic matter contents and maize performance on two contrasting degraded alfisol in Southwestern Nigeria. Int. Recycl. Org. waste Agric. 2019;8:73-80.

65. Dick WA, Juma NG, Tabatabai MA. Effects of soils on acid phosphatases and inorganic pyrophosphatase of corn roots. Soil. Sci. 1983;136: 19-25.

66. Marchand C, St-Arnaud M, Hogland W, Bell TH, Hijri H. Petroleum degrading capacity of bacteria and fungi isolated from petroleum contaminated soil. Inter. Biodeter. Biodegrad. 2017;116:48-57.

67. Qin W, Fan F, Zhu Y, et al. Anaerobic biodegradation of benzo(a) pyrene by a novel Cellulosimicrobium cellulans CWS2 isolated from polycyclic aromatic hydrocarbon contaminated soil. Brazil J. Microbiol. 2018;49(2):258-268.

68. Hamoudi-Belarbi L, Hamoudi S, Belkacemi K, et al. Bioremediation of polluted sites with crude oil hydrocarbons using carrot peel waste. Environments 2018;5(11):124.

69. Liang Q, Chen HQ, Gong, YS, Yang HF, Fan MS, Kuzyakov Y. Effects of 15 years of manure and mineral fertilizers on enzyme activities in particle-size fractions in a North China Plain soil. Eur. J. Soil Biol. 2014; 60:112-119.

70. Zhang X, Dong W, Dai X, et al. Responses of absolute and specific soil enzyme activities to long term additions of organic 
and mineral fertilizer. Sci. Total Environ. 2015; 536:59-67.

71. Trasar-Cepeda C, Leirós MC, Gil-Sotres F. Hydrolytic enzyme activities in agricultural and forest soils. Some implications for their use as indicators of soil quality. Soil Biol. Biochem. 2008;40:2146-2155.

72. Dzionek A, Wojcieszyńska D, Guzik U. Natural carriers in bioremediation: A review. Electron. J. Biotechnol. 2016;9(5):29-34

73. Chuaphasuk C, Prapagdee B. Effects of biochar-immobilized bacteria on phytoremediation of cadmium-polluted soil. Environ. Sci. Pollut Res. 2019;26:23679-23688.

74. Rong X, Chen W, Huang, Q, Cai P, Liang W. Pseudomonas putida adhesion to goethite: studied by equilibrium adsorption, SEM, FTIR and ITC. Colloids Surf. B.2010;80(1):79-85.

75. Tang J, Wang M, Wang F, Sun Q, Zhou Q. Eco-toxicity of petroleum hydrocarbon contaminated soil. J. Environ. Sci. 2011;23(5):845-851.

76. Njoku KL, Akinola MO, Oshodin OR. Phytotoxicity assay of crude oil using different accessions of Sorghum bicolor. World Appl. Sci. J. 2011;15(1):38-46.

77. Oyedeji AA, Adebiyi AO, Omotoyinbo MA, Ogunkunle CO. Effect of crude oil contaminated soil on germination and growth performance of Abelmoschus esculentus L. Moench-A widely cultivated vegetable crop in Nigeria. Am. J. Plant Sci.
2012;3:451-1454.

78. Iheme PO, Akinola MO, Njoku KL. Evaluation on the growth response of Peanut (Arachis hypogaea) and Sorghum (Sorghum bicolor) to crude oil contaminated soil. Appl. Sci. Environ. Manage. 2017;21(6):1169-1173.

79. Matulich KL, Martiny JB. Microbial composition alters the response of litter decomposition to environmental change. Ecology 2015;96(1):154-163.

80. Li L, Xu M, Ali ME, Zhang W, Duan Y, Li D. Factors affecting soil microbial biomass and functional diversity with the application of organic amendments in three contrasting cropland soils during a field experiment. Plos One. 2018;13(9):eo203812.

81. Fatima K, Imran R, Amin I, Khan QM, Afzai M. Successful phytoremediation of crude - oil contaminated soil at an oil exploration and production company by plants - bacterial synergism. Intl. J. Phytoremed. 2018;20(7):675-681.

82. Molina-Barahona L, Vega-Loyo L, Guerrero $M$, et al. Ecotoxicological evaluation of diesel-contaminated soil before and after a bioremediation process. Environ. Toxicol. 2005;20(1):100-109.

83. Adekunle IM. Bioremediation of soils contaminated with Nigerian petroleum products using composted municipal waste. Bioremed. J. 2011;15(4):230-241. 